\title{
Registros documentais no cinema da Revolução Mexicana
}

\author{
Maurício de Bragança*
}

\begin{abstract}
Resumo:
Este artigo pretende focar as relações entre cinema e história nas duas primeiras décadas do século XX no México. O cinema foi apresentado pela primeira vez no país em uma sessão dedicada a Porfirio Díaz. Percebendo seu potencial propagandístico, o ditador logo se converteria na primeira grande estrela do cinema mexicano. O cinema forjava-se como "documento histórico" stricto sensu, num registro da verdade inquestionável. A Revolução redefiniu seu papel, registrando a ebulição pela qual passava a sociedade em documentários que se distanciavam do mero aspecto da curiosidade espetacular para atingir uma verdadeira presença do realizador junto ao cenário político nacional. $\mathrm{O}$ desdobramento da Revolução, com a superação da fase insurrecional, e o processo de domesticação do discurso revolucionário no âmbito oficial acabaram por esvaziar o teor de contestação das imagens documentais. A imagem do corpo de Zapata assassinado, que circulou pelo território nacional, é um emblema deste projeto.
\end{abstract}

Palavras-chave: cinema, história, Revolução Mexicana

As relações entre cinema e história apresentam complexidades de diversas naturezas, entre ética, epistemológica e, sobretudo, metodológica. Neste sentido, ao se trabalhar a textualidade produzida pelo cinema como uma fonte rica e vigorosa para o historiador, é necessário tomar alguns cuidados e é imprescindível tecer algumas discussões pertinentes ao campo das interdisciplinaridades. Metodologicamente, podemos afirmar que o engajamento do historiador ao campo cinematográfico se constrange de um método stricto sensu, como já o localizou Phillipe Dubois, mas há um instrumental a ser utilizado e há, sobretudo, uma tomada de posição do historiador.

E, nesse sentido, as discussões sobre cinema e história ampliam suas bases para posturas éticas do pesquisador diante do objeto estudado e, principalmente, diante do cinema (e da cultura visual de um modo mais amplo) como registro de fonte documental. E aqui residem os primeiros problemas para os pesquisadores interessados no "uso de imagens como evidência histórica" (Burke, 2004, p.11). Nas últimas décadas, a interrogação da imagem foi reprocessada sob uma perspectiva que colocava o estudo da cultura como um ponto central para as ciências humanas, conduzindo, segundo Knauss (2006, p.107), a uma "revisão do estatuto do social". 
Nesse contexto, o lado subjetivo das relações sociais ganhou espaço e consolidou uma tendência que passou a sublinhar como a cultura - o sistema de representações - instigava as forças sociais de um modo geral, não sendo mero reflexo de movimentos da política ou da economia. A virada cultural destacou os vínculos entre conhecimento e poder, o que serve, igualmente, para demarcar o estudo das imagens. A cultura visual seria, portanto, um desdobramento de um movimento geral de interrogação também sobre a cultura em termos abrangentes. (ibidem)

Neste sentido, torna-se importante recuperar as discussões propostas por Jacques Le Goff no célebre artigo Documento/Monumento, no qual o autor, recuperando uma espécie de construção dos discursos da tradição sobre o monumento, lugar de reafirmação de uma memória coletiva, problematiza as relações entre história/documento/monumento, alargando o conceito de documento (gesto já iniciado desde os fundadores da École des Annales) e partilhando, inclusive, da idéia foucaultiana de suspeitar do monumento. Numa espécie de síntese de seu pensamento, Le Goff sentencia:

\begin{abstract}
A intervenção do historiador que escolhe o documento, extraindo-o do conjunto dos dados do passado, preferindo-o a outros, atribuindo-lhe um valor de testemunho que, pelo menos em parte, depende da sua própria posição na sociedade da sua época e da sua organização mental, insere-se numa situação inicial que é ainda menos "neutra" do que a sua intervenção. O documento não é inócuo. É antes de mais nada o resultado de uma montagem, consciente ou inconsciente, da história, da época, da sociedade que o produziu, mas também das épocas sucessivas durante as quais continuou a viver, talvez esquecido, durante as quais continuou a ser manipulado, ainda que pelo silêncio. O documento é uma coisa que fica, que dura, e o testemunho, o ensinamento (para evocar a etimologia) que ele traz devem ser em primeiro lugar analisados desmistificandolhe o seu significado aparente. O documento é monumento. Resulta do esforço das sociedades históricas para impor ao futuro - voluntária ou involuntariamente - determinada imagem de si próprias. No limite, não existe um documento-verdade. Todo o documento é mentira. Cabe ao historiador não fazer o papel de ingênuo. Os medievalistas, que tanto trabalharam para construir uma crítica - sempre útil, decerto - do falso, devem superar esta problemática porque qualquer documento é, ao mesmo tempo, verdadeiro - incluindo, e talvez sobretudo, os falsos - e falso, porque um monumento é em primeiro lugar uma roupagem, uma aparência enganadora, uma montagem. (Le Goff, 1996, p.547-8)
\end{abstract}

A conclusão de Le Goff sobre a aparência de verdade que encobre o documento vai ao encontro de Ismail Xavier (2005) quando, ao analisar o caráter de dissimulação do cinema, convoca-o a partir da chave "revelação-engano". Nestas considerações também são descartadas - ou ao menos profundamente relativizadas quando o objeto é o cinema - a idéia de verossimilhança e fidelidade. Isso não quer dizer que a história não esteja presente na articulação do texto cinematográfico, ao contrário, ela apresenta parâmetros para construção do discurso cinematográfico, não se constituindo um mero pano de fundo ou contexto. As relações entre cinema e história se apresentam, portanto, muito mais complexas e problemáticas. 
Nas articulações possíveis e necessárias entre o campo da história e o campo da cultura visual estão imbricadas discussões acerca das linguagens, das representações e das práticas sociais que oferecem os aportes imprescindíveis para a problematização das relações entre as formas simbólicas e o mundo social, como muito bem apontou Roger Chartier (2006) em um ensaio em que interroga a "nova história cultural". Localizando o campo de disputa em que se situa a política de representações culturais no âmbito da história, Chartier elucida:

A uma abordagem clássica, ligada à localização objetiva das divisões e das diferenças sociais, ela [a nova história cultural] opõe a sua construção móvel, instável, conflitual, a partir das práticas sem discurso, das lutas de representação e dos efeitos performativos dos discursos. (idem, p.29)

Tais discussões já haviam sido sistematizadas nos estudos do historiador Marc Ferro (1976), cujo clássico texto “O filme: uma contra-análise da sociedade?” tornou-se referência para muitos historiadores que se debruçavam sobre o filme como forma de interrogar a história. Ferro (idem, p.202) lança a questão sobre o aspecto de representação de realidade apreendida, ou reconduzida, pelo cinema: "de que realidade o cinema é verdadeiramente a imagem?" Assim, o historiador francês parece apontar o foco sobre os esquemas de representação, tornando mais espinhosa a questão da apropriação e manipulação dos discursos sobre a imagem e a própria produção da imagem em si.

No encaminhamento dessas preocupações, os historiadores já admitem que "a imagem não ilustra nem reproduz a realidade, ela a reconstrói a partir de uma linguagem própria que é produzida num dado contexto histórico" (Kornis, 1992, p.238). O cinema assume, assim, um local privilegiado como fonte capaz de apontar caminhos para a análise de comportamentos, de práticas sociais e políticas, e de projetos ideológicos em um determinado momento histórico. Isso possibilita descartar, de uma certa forma, a recorrência ao cinema como possibilidade de uma simples descrição da sociedade, como se o filme se prestasse a uma utilização como um parâmetro de confirmação da estrutura social apreendida em análises alheias ao objeto fílmico.

As posições de Marc Ferro têm sido questionadas por autores como Eduardo Morettin (2007), que aponta que, para o historiador francês, o cinema se apresenta como confirmação daquilo que o texto histórico indica, não conferindo relevância à textualidade da linguagem do cinema. Ao pensar as relações entre cinema e história a 
partir de dicotomias como "aparente" - "latente", "visível" -, "não visível" ou ainda "história" - "contra-história", Ferro despreza, segundo as considerações de Morettin, o caráter polissêmico da imagem, já que a obra cinematográfica seria vista como portadora de dois níveis de significado independentes. "Pelo contrário, afirmamos que um filme pode abrigar leituras opostas acerca de um determinado fato, fazendo dessa tensão um dado intrínseco a sua própria estrutura interna” (Morettin, 2007, p.42). Para Morettin, Ferro nunca tomou de fato o cinema como objeto empírico para colocar em questão sua idéia do filme como contra-análise, passível de ser feito prioritariamente pela análise fílmica, quando o filme é "alçado ao primeiro plano" (idem, p.61). Somente a análise fílmica, para o pesquisador brasileiro, é capaz de recuperar o significado de uma obra cinematográfica, extraindo do filme as questões pertinentes a sua própria natureza enquanto objeto específico.

Com esse movimento, evitamos o emprego da história como pano de fundo, na medida em que o filme não está a iluminar a bibliografia selecionada, ao mesmo tempo que não isolamos a obra de seu contexto, pois partimos das perguntas postas pela obra para interrogá-lo. Dessa forma, impedimos que o cinema seja sufocado pela pesquisa histórica ... (idem, 2007, p.63)

Neste artigo pretendemos apresentar as problemáticas discussões entre cinema e história a partir da experiência dos documentários mexicanos da primeira e segunda décadas do século XX de forma que demonstre toda a complexidade deste diálogo. A história, sobretudo nos documentários que focaram a Revolução Mexicana, teve um papel para além de um mero contexto ou como pano de fundo, assim como os filmes nunca se colocaram como um simples sintoma do projeto histórico. Desta forma, as relações entre história e cinema apresentam um nível de complexidade que pretendemos adensar através da abordagem deste repertório fílmico produzido no México.

$\mathrm{O}$ cinema chegou ao México pela equipe dos irmãos Lumière em agosto de 1896, oito meses depois de apresentado pela primeira vez em Paris, e estreou numa sessão dedicada ao ditador Porfirio Díaz no Castelo de Chapultepec. A novidade teve uma grande repercussão na imprensa, que recebeu positivamente a "admirável invenção do aparato prodigioso". O jornal católico El Tiempo publicava, no dia 13 de setembro de 1896, uma elogiosa matéria que lamentava apenas que nas imagens que se haviam tomado da Cidade do México, e que chegariam a outras Nações, “... aparezcan tantos encamisados y tantos sucios ..." (De los Reyes, 1973, p.23). 
Logo alguns empresários se interessariam em comprar o equipamento de filmagem e projeção da empresa Lumiére e passariam a viajar pelo interior do país para captar imagens que seriam exibidas ao público mexicano. Um desses empreendedores foi o engenheiro italiano Salvador Toscano, que acabou se convertendo numa figurachave deste primeiro momento do cinema mexicano. Esta produção cinematográfica vinha impregnada de uma postura positivista, confirmando o cinema como um aparato científico que deveria registrar "a verdade" tal como era vista pelos olhos.

Numa primeiríssima fase deste cinema mexicano, que o historiador Aurelio de los Reyes (1973) situa entre 1896 e 1900 aproximadamente, a tendência era captar a realidade exterior num tipo de apreensão da imagem muito próxima à representação pictórica indicada pelas artes plásticas. A SIP (Secretaria de Instrução Pública), percebendo o potencial propagandístico do cinematógrafo, acabou convertendo o ditador Porfirio Díaz na primeira grande estrela do cinema mexicano, visto em pequenos registros documentais como El general Díaz despidiéndose de sus ministros, El general Díaz y sus ministros en Chapultepec, El general recorriendo el Zócalo, Grupo en movimiento del General Diaz y de algunas personas de su familia ou El General Diaz paseando a caballo en el bosque de Chapultepec (Luna, 1979). O presidente, inclusive, foi o protagonista do primeiro filme de larga metragem mexicano de que se tem notícia, o documentário Fiestas presidenciales en Mérida, filmado em 1906 pelo cinegrafista Enrique Rosas (Orozco; Bernal, 1985; Luna, 1979). Aos representantes da Lumière interessava difundir pelo mundo o novo invento e para isso a aproximação com os governantes era uma estratégia fundamental. Assim fora com Porfirio Díaz no México, com Félix Faure na França, com o imperador da Alemanha, com o czar russo, com a infanta Isabel de Espanha.

\footnotetext{
Díaz contaba con todos los tributos para constituirse en el primer héroe cinematográfico nacional. Su carisma fue aplaudido en aquellas imágenes en las que la mejor sociedad mexicana (aquella que tenía la decencia a flor de piel, el apellido antañón y amaba a la patria en la medida en que ésta es muy redituable) lo veía como un titán que preservaba el orden y el progreso con su poca política y mucha administración. (Luna, 1979, p.51)
}

Simultaneamente à chegada dos representantes da Lumière no México, chegavam também as sessões do Vitascopio de Edison, iniciando uma concorrência programada entre os franceses e os norte-americanos. Contudo, diferentemente da Companhia de Lumière, os filmes apresentados pelo Vitascopio eram fabricados em estúdio e contavam pequenas histórias de curta duração destinadas à diversão do 
público. As produções Lumière, além do entretenimento - que naquele final de século já era praticamente garantido devido ao assombro que despertava a novidade - , tinham também o objetivo de instruir e informar.

O cinematógrafo viria confirmar, no final do século XIX, o êxito de uma administração baseada numa idéia de "civilização e progresso". O imenso desenvolvimento de uma malha ferroviária, a luz elétrica, o processo de industrialização que se iniciava, a instalação de um sistema de iluminação pública (que era acompanhada com deslumbramento pela população que se emocionava diante da mágica das lâmpadas acesas), as obras de saneamento, a pavimentação das ruas, o projeto de planejamento urbano, tudo indicava os indícios de prosperidade econômica conseguida pela ditadura de Don Porfirio. O mundo foi testemunha das conquistas do projeto civilizatório mexicano na Exposição Universal de Paris, em 1900, quando o governo, ao escolher o modelo de construção de um pavilhão no melhor estilo clássico francês, descartava um outro projeto que propunha a construção de um prédio de características aztecas, já que era necessário afastar do imaginário internacional a idéia de um México ligado à "selvageria" pré-colombiana. O cinema, que era também fruto desse desenvolvimento industrial, tornava-se cúmplice desse progresso.

Por outro lado, esse progresso não chegava às periferias da capital e do país, que apresentavam condições de vida cada vez mais precárias sob um forte modelo de exclusão social da grande maioria das camadas populares. Para tais multidões, que começavam a chegar às cidades, os inventos trazidos pela modernização e pelo progresso não tinham, porém, um aspecto científico, mas sugeriam uma forma de entretenimento e diversão.

De todas as novidades que apareciam como aparatos modernos, o cinema foi o que teve uma difusão e aceitação mais generalizada, por um preço muito mais reduzido que outras diversões. Em apenas três anos, o valor da entrada para uma sessão de projeção de filmes numa das 22 salas de cinema que já se espalhavam pela Cidade do México havia baixado muito. Do valor de um peso - o mesmo que custava um assento na sombra na Plaza de Toros ou um lugar num camarote com luneta na ópera - passou a cinco ou três centavos (De los Reyes, 1997). Isso impulsionava a rápida popularização do cinema, que deixava de ser visto apenas como objeto de curiosidade científica (a partir dos estudos realizados para captação dos movimentos) e passava a ser experimentado como espetáculo de diversão pública. 
A popularização do cinematógrafo era vista pelas classes mais abastadas como uma "vulgarização científica". Assim, os intelectuais foram abandonando suas esperanças no invento, que rapidamente se distanciava de seu aspecto "científico".

Durante los primeros seis meses después de su llegada a la Ciudad de México, el cine fue aceptado por todos los círculos sociales, pero pronto, literatos, científicos y algunos voceros de la sociedad lo menospreciaron por haberse convertido en un espectáculo ciento popular. A sus ojos se había convertido en un aparato de "vulgarización científica”. (De los Reyes, 1973, p.65)

Embora ainda não se atribuísse um valor artístico ao cinematógrafo, e sim científico, a "estética" do invento seguia as ditadas pela arte naturalista do momento, que buscava captar a vida mexicana, ou o recorte que se fazia dela, em todos os seus detalhes ao demonstrar acima de tudo a "verdade" do assunto: reproduzir a paisagem mexicana, captando as cenas de costumes do país, para informar seu povo e o estrangeiro.

Os primeiros filmes apresentavam simples cenas corriqueiras que se assemelhavam à pintura. Os cinegrafistas necessariamente se inspiravam na Natureza para a elaboração de seus filmes, dando uma olhada na realidade exterior. Por isso esses filmes eram chamados de "vistas", nos quais se reproduzia a preocupação de pintores e literatos em captar o mundo exterior (De los Reyes, 1981). Desta forma se construía uma forte ligação entre a imagem cinematográfica e a idéia de realidade. O público reagia à aparição do general Porfirio Diaz na tela com entusiasmados aplausos assim como gritava olé e lançava seus sombreros ao ar em filmes de touradas, reproduzindo um comportamento de fora das salas de cinema e criando novas formas de sociabilidade a partir do "ato social de ir ao cinema". Numa crônica publicada no jornal El Universal do dia 27 de março de 1917, Hipólito Seijas descrevia o comportamento popular num típico cinema dos arrabaldes da cidade: "parece un mercado y no un lugar de espectáculos”. A intensa participação do público durante as sessões era algo sempre destacado.

\begin{abstract}
De repente la vista se pone fuera de foco y el público, como si se pusiera de acuerdo, comienza a patear; y si no le hacen caso, grita y se pone iracundo como un chiquillo, y si el operador no arregla con violencia el momentáneo desperfecto, los asistentes son capaces de destruir el cobertizo. La misma psicología de la multitud, cuando sale un toro manso o un auto no corre en la pista. (SEIJAS apud CASANOVA, 1992, p.144)
\end{abstract}

O cinema produziu, sem a necessidade dos artifícios da pintura, a ilusão de verdade. Cinematógrafo e kinetoscópio tornaram-se sinônimos de verdade. As "vistas" 
mexicanas se caracterizavam por refletir a vida mexicana: feitos importantes da vida nacional, festas pátrias, viagens do general Diaz, touradas e cidades de província. Cinema como documento histórico, já que a realidade poderia ser captada em toda a sua integridade. Para os intelectuais, graças a estes aparatos não era possível adulterar a história com notas tendenciosas.

Os empresários ambulantes percorriam o interior do país filmando aspectos da vida das cidades e exibindo-os a seus públicos até esgotar seu potencial, num cinema que se forjava sob um forte sentido de transumância (De los Reyes, 1973, 1997). No melhor estilo Lumière, esses empresários-cinematografistas registravam as imagens das pessoas em seus passeios de domingo, a saída das missas, o fim de expediente da fábrica, casamentos, festas oficiais e, sobretudo, o general Porfirio Díaz. Esses homens de cinema convertiam-se em produtores-cinegrafistas-exibidores, difundindo as imagens documentais mexicanas. E a história mexicana registrada pelo cinema tornava-se cada vez mais próxima ao discurso oficial da "belle époque" porfirista.

No último mandato de Don Porfirio (1904-1910), as câmeras se detinham em mostrar o progresso e o desenvolvimento alcançados pelo projeto da Pax Porfiriana, sob o lema positivista de "ordem e progresso". Enquanto as cerimônias oficiais despertavam a curiosidade das lentes do cinema - como o encontro entre Porfirio Díaz e o presidente dos Estados Unidos William Taft -, acontecimentos como os massacres dos trabalhadores pelas tropas do governo durante as greves de Cananea (1906) e Río Blanco (1907), mantinham-se longe das telas.

A Revolução de 1910 redefiniu o papel do cinematógrafo, registrando a ebulição pela qual passava a sociedade mexicana em documentários que aos poucos foram se distanciando do mero aspecto da curiosidade espetacular para atingir uma verdadeira presença do realizador junto aos movimentos que agitavam o cenário político nacional. A produção cinematográfica multiplicou-se entre 1910 e 1913, atingindo certa maturidade técnica e estética. A Revolução trazia mudanças importantes na realização documental, como uma complexidade na ordenação de imagens e o oferecimento de uma reportagem de um fato histórico como único número do programa (De los Reyes, 1986, p.14). Para o historiador do cinema mexicano Aurelio de los Reyes (1997), esta é a verdadeira Época de Ouro do cinema mexicano, quando o movimento revolucionário torna-se o grande protagonista, dividindo a cena com os filmes que retratavam o dia-adia da capital. Desde que chegara ao país, o cinema seguia majoritariamente dedicado ao registro documental. 
O documentário da Revolução ainda era marcado por um olhar naturalista, que exigia "objetividade e imparcialidade". Abundavam nesses filmes as cenas de violência que marcavam o movimento, como as chocantes imagens da incineração de cadáveres vítimas da Dezena Trágica (etapa da Revolução que, em 1913, chegou à capital do país), onde os corpos eram empilhados em enormes montanhas nas ruas da Cidade do México.

O cinema apresentava a prova inconteste da História. De los Reyes revela que o próprio assassinato de Emiliano Zapata em Chinameca, em 1919, havia sido filmado por um cinegrafista oculto, sob encomenda do señor Jesus Guajardo, cuja intenção era a de receber uma prova irrefutável de que o morto era de fato o temido líder de Morelos (De los Reyes, 1981, p.229).

O público se identificava com o momento histórico projetado na tela. As sessões de cinema convertiam-se em verdadeiras manifestações políticas, com uma ruidosa participação do público, que assobiava e aplaudia os grupos e chefes das facções. A consciência da importância do registro dessas imagens fazia com que cada líder revolucionário mantivesse seus próprios fotógrafos e cinegrafistas. Os irmãos Alva acompanhavam Madero, filmando os acontecimentos ocorridos tanto na capital quanto no interior do país. Jesús Abitia registrou campanhas de Obregón e deslocamentos de Venustiano Carranza. Villa teve uma íntima ligação com diversos cinegrafistas norteamericanos de algumas companhias de cinema que registravam suas batalhas e com quem inclusive o temido Leão do Norte assinou um contrato para um filme sobre a sua vida ${ }^{1}$. Os zapatistas também se deixaram filmar por alguns cinegrafistas (De los Reyes, 1992).

La Revolución estimuló la conciencia histórico-visual de los fotógrafos y de los caudillos. Agustín Víctor Casasola lo expresó claramente durante una exposición de los fotógrafos de prensa en 1911: "somos impresionadores del instante, esclavos del momento", afirmó en su discurso inaugural ante el presidente interino Francisco León de la Barra. (De los Reyes, 1997, p.52)

Assim, por desgaste, e por "alterar a ordem pública", o governo começava a impor travas à realização e circulação desse tipo de "perigoso material", que pouco a pouco foi deixando de ser produzido. Em 1913 foi publicado um Reglamento de cinematógrafos com vistas a regular e censurar a produção de filmes que "alterassem a ordem". Junto a essas normas, foram publicados pela primeira vez na história do país 
decretos restringindo a prática do cinema por perceber o perigo que este poderia exercer junto às massas (Orozco \& Bernal, 1985).

$\mathrm{Na}$ fase constitucionalista encarnada na figura de Venustiano Carranza, era necessário derrotar as forças insurrecionais e recuperar a ordem através da pacificação do território. Além disso, as imagens da revolução chegavam ao exterior, principalmente aos vizinhos Estados Unidos, confirmando, segundo o governo constitucionalista, uma imagem do mexicano que historicamente vinha sendo retratada no cinema gringo: bandoleiro, sanguinário, violento, bárbaro, bêbado, selvagem e absolutamente passional. Este de fato não era o interesse do governo nacionalista que precisava urdir com habilidade a domesticação e institucionalização do processo revolucionário.

Os próprios líderes camponeses que combatiam as tropas federais tinham bastante consciência de sua auto-imagem e, neste sentido, vale a pena determo-nos especialmente sobre a imagem construída de Pancho Villa, o líder dos exércitos da Divisão do Norte. Os jornalistas norte-americanos tinham muito interesse sobre a personagem de Francisco Villa, que era retratado pela imprensa nos Estados Unidos, em fins de 1913, como uma espécie de herói popular equiparado a Robin Hood, por sua generosidade, e a Napoleão, por seu gênio militar. O jornalista marxista britânico John Reed chegou ao México como correspondente de The World e Metropolitan Magazine em fins de 1913, acompanhado de uma câmera fotográfica e outra cinematográfica a fím de conhecer de perto o temido revolucionário para que pudesse escrever seu futuro clássico relato México Rebelde, que seria publicado em folhetim no Metropolitan Magazine a partir de abril de 1914 (De los Reyes, 1992).

Entre 1914 e 1916, Villa foi sem sombra de dúvida a personagem da revolução mexicana que mais interesse e curiosidade despertou no fotojornalismo cinematográfico norte-americano. É importante lembrar que a irrupção da Revolução Mexicana coincide com o início do fotojornalismo cinematográfico nos Estados Unidos e, portanto, converteu-se num estímulo para os jovens repórteres cinematográficos ${ }^{2}$. Durante a Revolução, esses profissionais puderam testar novos equipamentos cinematográficos e desenvolver formas de narrativas nas reportagens de atualidade que seriam empregadas mais tarde nos filmes da I Guerra Mundial. A Revolução convertia-se, desta forma, numa espécie de laboratório para a pesquisa e o desenvolvimento desse modelo de produção de relato (De los Reyes, 1992). Isso reforça as advertências feitas pelo 
historiador Peter Burke (2004) ao pensar a utilização da imagem como "testemunho ocular":

... o significado das imagens depende do seu "contexto social". Estou utilizando esta expressão num sentido amplo, incluindo aí o "contexto" geral, cultural e político, bem como as circunstâncias exatas nas quais a imagem foi encomendada e também seu contexto material, em outras palavras, o lugar físico onde se pretendia originalmente exibi-la. Nesta visão resumida de enfoques mais ou menos novos para a imagem, há um lugar para a história social e cultural. (Burke, 2004, p.225)

Pancho Villa tinha uma grande intuição publicitária e contava, em suas filas, com as melhores equipes de cinegrafistas norte-americanos que relatavam seus feitos com as mais fantásticas técnicas de espetacularidade narrativa. Harry E. Aitken, presidente da Mutual, chegou a mandar fabricar em San Antonio, no Texas, oito câmeras de desenho especial que pudessem ficar no alto ao filmar as batalhas de modo que o operador expusesse a máquina sem expor sua própria vida. Villa passou a se preocupar, inclusive, com sua apresentação pessoal e de seu Exército por conta da má impressão que havia causado nos Estados Unidos através de filmes que o mostravam sujo e desarrumado, com roupas rasgadas ${ }^{3}$. Segundo De los Reyes (1992, p.41-2), em janeiro de 1914 Francisco Villa firmou o primeiro contrato com a Mutual Film Corporation, para que estes pudessem realizar um filme autobiográfico do general que contava, entre outras cláusulas,

que Mutual ... tenía el derecho de exhibir las películas en la zona liberada por Villa y la totalidad de los Estados Unidos y Canadá; si los camarógrafos no captaban buenas escenas de batallas, Villa se comprometió a fingirlas y a no permitir que operadores y fotógrafos de otras compañías lo retrataran. Los beneficios económicos se repartirían al 50\%, a cuenta de los cuales recibió veinticinco mil dólares. Villa se reservaba el derecho de exhibir las películas a sus hombres y se comprometió a efectuar los ataques a la luz del día.

O novo documentário mexicano nascia, a partir de 1916, com o governo de Carranza, com um forte cunho nacionalista oficialista que objetivava levar ao exterior a imagem de um México já apaziguado, filiando-se inclusive aos preceitos porfiristas de propagandismo político (um cinema "científico" para difundir os "progressos" do país). Era necessário divulgar a "vitória" da Revolução como obra de "reconstrução nacional".

As sucessivas derrotas dos exércitos de Pancho Villa pelas tropas carrancistas chefiadas por Álvaro Obregón acabaram por modificar a imagem de Pancho Villa nos relatos feitos por norte-americanos. Não podemos deixar de enfatizar que é nessa época 
que se normalizam as relações entre México e Estados Unidos, conturbadas durante o período de governo do general Huerta. Do tom laudatório da imagem heróica do líder da Divisão do Norte, passou-se a uma narrativa de western na qual Pancho Villa convertiase em um notório bandido e assassino mexicano foragido das forças legais. Em 1916, dois cinegrafistas, Tracy Mathewson (a serviço da Hearst) e Leland J. Burrud (da Gaumont) foram autorizados a acompanhar a expedição punitiva que foi ao México para caçar o temido general.

O novo documentário elegia um ângulo muito bem definido da realidade: o progresso, as belezas naturais e os atos oficiais. Não havia oposição política nesses filmes e nada se falava das frentes zapatistas e villistas que continuavam combatendo contra o governo carrancista. O nacionalismo deste cinema documentário tirou do foco a gente comum. Não há muitos registros, nesta época, de imagens de fábricas, campos, ruas das cidades, saída das missas. Era o sonho de um México tranqüilo, em ordem e progresso.

\footnotetext{
En esta etapa no se concibe al cine como un medio capaz de analizar la realidad social, sino más bien como un espectáculo que con un poco de suerte puede dar beneficios económicos. Ahora bien, con todo, se le reconocía al cine un potencial educativo y moralizador útil para reflejar una adhesión básica a los valores establecidos. En efecto, los realizadores de la época no se creen obligados a apoyar el nuevo orden de las cosas pero, en el fondo, se sienten agradecidos al constitucionalismo de que finalmente haya exorcizado al demonio de la insurrección campesina. Así se explican las veladas referencias a las milicias zapatistas como "facciones sediciosas" o bien como "los elementos que asolaron al país durante varios años y cometieron toda clase de atropellos". ... (Orozco; Bernal, 1985, p.17)
}

Assim, as práticas políticas envolvidas nos modelos de representação, sejam elas individuais ou coletivas, ganham espaço na análise de tais documentários, confirmando as relações que se processam entre tais modelos e as próprias divisões do mundo social. São essas representações, segundo Chartier (2006, p.39), que "suportam as diferentes modalidades de exibição de identidade social ou de força política, tal como os signos, os comportamentos e os ritos os dão a ver e crer”.

Em 1950, Carmen Toscano toma a rica produção deixada por seu pai, o engenheiro e cinegrafista Salvador Toscano, e, através da montagem desse material, parte em busca da memória coletiva do povo mexicano da primeira metade do século XX, resultando num filme intitulado Memorias de un Mexicano.

Numa edição pautada pelo emblema familiar, própria do espaço privado articulado pela linguagem do melodrama - hegemônico na produção audiovisual daquele momento -, a filha do cineasta pretendia construir um discurso que definisse a 
identidade mexicana da primeira metade do século XX a partir da escolha de um repertório comum: ritos, crenças, mitos históricos e legados heróicos articulados no interior do registro memorial. A narração presente no filme constrói a história de sua própria família, tecendo-a com o cenário nacional. Assim, as desavenças familiares narradas refletem a própria correlação de forças políticas que dividiam também a sociedade mexicana. A linguagem do melodrama no cinema, tanto de ficção como documental, naquele momento, contribuía para pautar a agenda política nacional junto aos grandes públicos. A partida de Porfirio Díaz para Paris, em 1911, narrada sob forte carga nostálgica no filme da filha de Toscano, também significa a partida de seu pai, o documentarista Toscano, que acompanha o velho ditador na viagem ao exílio.

Todos os espaços dessa memória devem ser preenchidos, não deixando margem para lacunas e fissuras no projeto histórico da Nação. A história e a memória articuladas no interior do discurso fílmico de Memorias de un Mexicano não assume a lacuna e o esquecimento como partes integrantes do conceito de memória, numa perspectiva autoritária e totalizadora da história que, ao assumir uma filiação épica de discurso do tipo "meninos: eu vi!", silencia resistências a esse discurso hegemônico. Constrói-se desta forma uma noção de identidade coletiva fundada num ato que, como diria Ricoeur, "proíbe o esquecimento", articulando o registro da memória à identidade como "a manutenção de si mesmo através do tempo" (Ricoeur, 2000).

As conquistas da Revolução deviam aniquilar o caráter traumático provocado pelo horror das imagens dos cadáveres incinerados na capital da República em 1913. O apagamento do conflito, projeto político da vitoriosa classe média que acabou por assumir o controle e o destino do processo revolucionário, se materializa sobre a emblemática imagem do corpo de Zapata assassinado. Essa imagem, que percorreu o território e a consciência da Nação, logrou domesticar o brado libertário dos indígenas aviltados que não conseguiram fazer valer seu projeto agrário. Emiliano Zapata, emblema maior do projeto fracassado de revolução social, já poderia, então, ocupar seu assento no panteão dos heróis da Revolução Mexicana por conta de uma memória que se institucionaliza através do esquecimento promovido pela grande narrativa sustentadora da "coesão social nacional".

$\mathrm{Na}$ última seqüência do filme, vemos sucessivas imagens do monumental desenvolvimento da capital do país, com seus modernos arranha-céus da década de 1940, suas amplas avenidas e seu movimento frenético porém ordenado, escolas públicas, modernos trens, plano detalhado de máquinas em funcionamento, que se 
fundem com imagens do passado para terminar num plano aberto de uma avenida da cidade onde ao fundo se vê o Monumento a la Revolución. Sobre essas imagens o narrador sentencia:

\begin{abstract}
México ya no es la vieja ciudad en que nascí. Un ritmo más acelerado parece mover a la nación, pero en el fondo del nuevo México viven los ideales del pasado: la libertad, el derecho, la justicia. Lo mismo en la independencia que en la Reforma y que en la Revolución hay un pueblo invariable en sus luchas y en sus esperanzas que no han sido en van. Parecen mirar las imágenes del pasado y descobriren las arterias de la ciudad y siento que algo de mi mismo habrá de perdurar mientras el recuerdo de lo que he vivido palpite en la memoria de cualquier mexicano.
\end{abstract}

As memórias de um mexicano transformam-se em memórias de todos os mexicanos, num efeito totalizador sobre o qual as articulações entre memória e esquecimento, memória e identidade e memória e poder pensadas por Halbwachs (1997) nos ajudam a refletir. $\mathrm{O}$ discurso editado por Toscano apresenta-se monológico: não existem versões, mascarando a lembrança que se articula dialeticamente a múltiplas formas de esquecimento - relação essa fundamental para a problematização do conceito de memória -, como nos indica Huyssen (2005): o esquecimento como memória impedida, como memória manipulada, como esquecimento comandado.

O discurso historiográfico linear e positivista construído pela edição da filha de Toscano, ao produzir sentido à obra do pai, hierarquiza memórias, tornando visíveis as marcas da organização de sentidos em torno de uma história oficial, detentora da memória nacional, e silenciando memórias subalternizadas no interior deste processo uníssono. Porém, como nos diz Andreas Huyssen (2000, p.68),

\footnotetext{
... a memória coletiva de uma sociedade não é menos contingente e instável; de modo nenhum é permanente sua forma. Está sempre sujeita à reconstrução, sutil ou nem tanto. A memória de uma sociedade é negociada no corpo social de crenças e valores, rituais e instituições. No caso específico das sociedades modernas, ela se forma para espaços públicos de memória tais como o museu, o memorial e o monumento.
}

Vale lembrar que o filme documental Memorias de un Mexicano foi declarado monumento histórico do México em 1967, pelo governo do general Gustavo Díaz Ordaz, responsável no ano seguinte pelo massacre dos estudantes na Plaza de Tlatelolco, quando estes reivindicavam uma nova inscrição na história.

Aqui nos reconduzimos ao início do texto quando trouxemos o artigo de Le Goff ao tomar o conceito de documento de forma mais ampla, onde o filme é convocado a desmontar a aparência enganadora que o constrói, num gesto em que "é preciso começar 
por desmontar, demolir esta montagem, desestruturar esta construção e analisar as condições de produção dos documentos-monumentos" (Le Goff, 1996, p.548).

\section{REFERÊNCIAS BIBLIOGRÁFICAS}

BURKE, Peter. Testemunha ocular: História e Imagem. Bauru, SP: Edusc, 2004.

CASANOVA, Manuel Gonzalez. Las vistas: una época del cine en México. México: INEHRM; Museo Casa de Carranza, 1992.

CHARTIER, Roger. A “nova” história cultural existe? In: LOPES, Antônio Herculano; VELloso, Mônica Pimenta; PESAVENTO, Sandra Jatahy (orgs.). História e linguagens: texto, imagem oralidade e representações. Rio de Janeiro: 7Letras, 2006.

DE LOS REYES, Aurelio. Medio siglo de cine mexicano (1896-1947). México: Trillas, 1997.

Con Villa en México: testimonios de camarógrafos norteamericanos en la revolución 1911-1916. México: UNAM, 1992.

. Filmografia del cine mudo mexicano. 1986-1920. México: Filmoteca de la UNAM, 1986.

. Cine y Sociedad en México 1896-1930. Vivir de sueños. Volúmen I (18961920). México: UNAM-Cineteca Nacional, 1981.

Los orígenes del cine en México (1896-1900). México: Unam (Cuadernos de Cine/21), 1973.

FERRO, Marc. O filme: uma contra-análise da sociedade? In: LE GOFF, Jacques; NORA, Pierre. História: novos objetos. Rio de Janeiro: Francisco Alves, 1976.

HALBWACHS, Maurice. La mémoire collective. Édition critique établie par Gerard Namer. Paris: Albin, Michel, 1997.

HUYSSEN, Andreas. Resistência à memória: os usos e abusos do esquecimento público. In: BRAGANÇA, Aníbal e MOREIRA, Sonia Virginia. Comunicação, Acontecimento e Memória. São Paulo: Intercom, 2005.

. Seduzidos pela memória. Rio de Janeiro: Artiplano, 2000.

KNAUSS, Paulo. O desafio de fazer História com imagens: arte e cultura visual. In: ArtCultura, n.12 (Dossiê História, Arte e Imagem). Uberlândia: UFU, Instituto de História, 2006. 
KORNIS, Mônica Almeida. História e cinema: um debate metodológico. In: Estudos Históricos, Rio de Janeiro, v.5, n.10, 1992, p. 237-250.

LE GOFF, Jacques. História e Memória. Campinas: Editora da Unicamp, 1996.

LUNA, Andrés de. La continuidad ideológica en los documentales sobre la revolución.

In: CASANOVA, Manuel González (org.). El cine y la Revolución Mexicana. Filmoteca Unam, 1979.

MORETTIN, Eduardo. O cinema como fonte histórica na obra de Marc Ferro. In: CAPELATO, Maria Helena; MORETTIN, Eduardo; NAPOLITANO, Marcos; SALIBA, Elias Thomé (orgs.). História e cinema. São Paulo: Alameda, 2007.

OROZCO, Federico Dávalos; BERNAL, Esperanza Vazquez. Filmografía general del cine mexicano (1906-1931). Puebla: Universidad Autónoma de Puebla, 1985.

RICOUER, Paul. La mémoire, l'histoire, l'oubli. Paris: Seuil, 2000.

TOURRENT, Tomás Pérez. La revolución mexicana vista por el cine internacional. In: CASANOVA, Manuel González (org.). El cine y la Revolución Mexicana. Filmoteca Unam, 1979.

XAVIER, Ismail. O discurso cinematográfico: a opacidade e a transparência. São Paulo: Paz e Terra, 2005.

BRAGANÇA, Maurício de. Pictures of the Mexican Revolution: cinema and politics in documentary records. História, São Paulo, v. 26, n. 2, p. 144-160, 2007.

Abstract: This article shows the connections between cinema and history in the two first decades in XX century in Mexico. The cinema arrived in Mexico in a session dedicated to Porfirio Díaz. The president soon became the first star movie in mexican cinema, interested in its publicity potencial. The movies were seen as historical documents that pointed the true. The Mexican Revolution redefined the cinema role showing the social movement by the contact between the filmaker and the national politic moment. The development of the revolution after its battle phase, and the process of institucionalization of its discourse in the official sphere removed the protest power from the documental images. The image of Zapata dead body went all the country through and became a emblem of this project.

Keywords: cinema, history, Mexican Revolution

Artigo recebido em 09/2007. Aprovado em 10/2007.

\section{NOTAS}


* Professor de História da América do Instituto de Filosofia e Ciências Sociais/UFRJ.

${ }^{1}$ Trata-se do mítico filme The life of Villa, produzido pela Mutual Film Corporation, dirigido por Raoul Walsh e Christy Cabane em Chihuahua. Segundo Tomás Pérez Tourrent (1979), este filme deveria ter sido dirigido por D. W. Griffith em 1913, mas o diretor americano estava envolvido com a produção de $O$ nascimento de uma nação. O próprio Walsh interpretou o papel de Villa mais jovem no filme. Esta experiência ficcional incluía imagens documentais do próprio Villa em combate.

2 Segundo Aurelio de los Reyes (1992), a Pathé's Weekly iniciou suas atividades em agosto de 1911, inaugurando o jornalismo cinematográfico nos Estados Unidos (que já havia sido iniciado pela própria Pathé's Weekly em 1909 na França). Em 1912 surgem a Gaumont Weekly e Animated Weekly, da Universal Film Manufacturing Company. Em janeiro de 1913, surge a Mutual Weekly e em 1914 a Hearst-Selig News Pictorial. Em 1916, a Selig-Tribune e a Hearst-Vitagraph News Pictorial.

${ }^{3}$ Segundo depoimentos de Charles Rosher, fotógrafo cinegrafista que acompanhou as tropas de Villa com sua câmera, o general da Divisão do Norte chegou a dirigir cenas de um funeral de um general correligionário: "Pancho Villa trató de ser director. Me pidió que filmara el funeral de un general. Los enemigos de Villa, las tropas federales, lo habían ejecutado amarrándolo a una vía y echando un tren encima de él. El funeral duró tres días. Yo apenas tenía material para medio día. Tuve que seguir dando vueltas a la manivela con la cámara sin película. No podía hacer otra cosa. No quería ser fusilado" (Browlow apud Tourrent, 1979, p.79). 